\title{
The role of farmers and organizational networks in climate information
} communication: the case of Ghana

\author{
Chidiebere Ofoegbu
}

Swedish Species Information Centre, Swedish University of Agricultural Sciences

(SLU), Uppsala, Sweden and African Climate and Development Initiative, University of Cape Town, South Africa, and

Mark New

African Climate and Development Initiative, University of Cape Town, Cape Town, South Africa

\begin{abstract}
Purpose - The nature of the collaborations that exists among the organizations in the climate change and agriculture sectors can influence the tailoring of climate forecasts into information useable for adapting agricultural practices to the risks posed by climate change. Also, the extent to which farmers are integrated into this organizational collaboration network can influence their access to climate information. This paper aims to examine how organizational collaborations in the process of climate information generation and dissemination acts as either barriers or enablers of farmers' access to and use of climate information in Ghana.

Design/methodology/approach - This study used key informant interview and questionnaire survey to interview the organizations in the climate change and agriculture sectors. Using network analysis as an analytical framework, the authors estimated the networks' core-periphery, density, reciprocity and degree centrality.

Findings - The authors observed that communication of climate information to farmers is mostly influenced by the collaborations between governmental organizations and nongovernmental organizations. Nevertheless, information flow and exchange through organizational collaboration network is having limited effect on improving farmers' knowledge about climate risks, impacts and available risk response options. This is mostly because the feedback flow of information from farmers to national level organizations has not been effective in addressing localized climate/agro challenges.
\end{abstract}

Originality/value - This paper provides a critical overview of key issues in influencing the relevancy and usefulness of climate information in the Ghanaian agriculture sector. Insights gained and recommendations

(C) Chidiebere Ofoegbu and Mark New. Published by Emerald Publishing Limited. This article is published under the Creative Commons Attribution (CC BY 4.0) licence. Anyone may reproduce, distribute, translate and create derivative works of this article (for both commercial and noncommercial purposes), subject to full attribution to the original publication and authors. The full terms of this licence may be seen at http://creativecommons.org/licences/by/4.0/legalcode

Research for this article was part of work on the project Adaptation at Scales in Semi-Arid Regions (ASSAR). We gratefully acknowledge funding received for the ASSAR project from the International Development Research Centre, Canada (IDRC) and Dept. for International Development, United Kingdom (DFID). The assistance provided by partners from the University of Ghana (Prince Ansah, Rahinatu Alare, and Lokoso Jimoh) towards the fieldwork component of this study is gratefully acknowledged. The authors would also like to indicate that the opinions expressed and conclusions arrived at, are those of the authors and are not of the sponsors.
Received 7 April 2020 Revised 5 August 2020 8 September 2020 Accepted 27 October 2020 information

communication

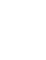


IJCCSM

13,1 made are essential for deploying effective climate services in Ghana and can be relevant for many African countries because of similar socioeconomic contexts.

Keywords Adaptation, Farmers, Climate change, Knowledge networks, Livelihood, Networks

Paper type Research paper

\section{Introduction}

The growing consensus on the reality of climate change has necessitated the need for societal actions to manage climate risk (Holler, 2014; Adger et al., 2001). Farmers in the semiarid regions in developing countries are highly sensitive to climate risk due to a range of factors that includes, for example, bad infrastructure, poor capital and reliance on rain-fed farming practice (Cadger et al., 2016; Cooper et al., 2008). Traditionally farmers in Ghana such as in many African countries have developed a variety of coping strategies to enable them cushion the effect of climate variability. However, the projected impact of climate change and the expected occurrence frequency of the associated extreme weather events is expected to be uncontainable for the farmers' traditional coping strategies (De Pinto et al., 2012; Fosu-Mensah et al., 2012).

Projected climate change scenario over Ghana indicates a likely increase in temperature by $1.6^{\circ} \mathrm{C}$ by 2050 , an increase in interannual rainfall variability and an increase in the intensity of rainfall event with a decrease in the number of rainy days (De Pinto et al., 2012; Kemausuor et al., 2011). These projections are anticipated to pose significant challenges for the numerous subsistence farmers in Ghana who are dependent on rain-fed farming systems (Ndamani and Watanabe, 2015; Fosu-Mensah et al., 2012). According to the World Bank collection of development indicators, $45.32 \%$ of Ghana population lives in the rural areas and are dependent on farming for livelihood (World Bank, 2013). Agriculture contributes about 35\% to Ghana's gross domestic product and employs approximately 55\% of the population (Fosu-Mensah et al., 2012). Farmers in Ghana are in most cases entirely reliant on rain-fed farming (Wossen et al., 2014).

The capacitation of farmers to facilitate the adoption of adaptation practices relies on comprehensive sharing of climate information (the term "climate information" as used in this study refers to information on climate risk warning and risk response strategy) among multiple stakeholders. Thus, the understanding of the structure and cohesion of the collaborative network existing among the organizations in the climate change and agriculture sectors has become critical (Kalafatis et al., 2015). Until recently, the communication of information to local farmers in Ghana follows the traditional pattern whereby scientific information generated through nationally managed information generation activity (with little or no input from local farmers) are disseminated via a topdown approach in which organizational structures and field extension workers are used to broker information to local users (Dayamba et al., 2018; Machingura et al., 2018; Ofoegbu and New, 2020). The efficiency of this model of climate information dissemination is hampered by the disproportionate ratio of local farmers to extension workers (Dayamba et al., 2018; Kemausuor et al., 2011). Similarly, the limited or nonengagement with local farmers in information generation activity often results in the dissemination of climate information that is not relevant to the context of local farmers, further hampering the efficiency of this model of climate information dissemination (Oreszczyn et al., 2010).

Only recently has the use of climate services (CS) to aid farmers' adaptation to climate change gained traction (Tall et al., 2018). Theoretically, farmers can use CS to make decisions on planting time; harvesting; application of irrigation, fertilizers, pesticides and insecticides; choice of crops to select; and whether to diversify their livelihoods (Ofoegbu 
and New, 2020). Studies have shown that rural farmers are interested in CS but the collaboration network for effective CS deployment are poorly understood (Cramer, 2017; Coulibaly et al., 2015; Cornell et al., 2013). Network analysis has emerged as an analytical framework for determining communication paths for CS deployment (Marın and Berkes, 2010; Bodin and Crona, 2009; Abrahamson and Rosenkopf, 1997). Bodin and Crona(2009) reported that network analysis can improve collaborative management practices by enabling the generation and transmission of different types of information about farming practices that are adaptive to climate change. Stott and Huq(2014) demonstrated that networks play crucial role in information exchange, resulting in more resilient agricultural practices. There is indeed a growing recognition by researchers and practitioners that the networks of relationships between organizations in the climate change and agriculture sector represent an untapped resource for facilitating farmers' adaptation to climate change (Cárcamo et al., 2014; Cash and Moser, 2000).

Despite the advances in the application of network analysis for understanding information flow (Dougill et al., 2016; Cárcamo et al., 2014; Bodin and Crona, 2009), the literature has fallen short of empirically examining how the organizational collaboration may influence information flow and adoption in a complex scenario, e.g. climate change and the farming sector. A gap, therefore, remains in the understanding of how organizational collaborations in the generation and dissemination of climate information can act as either barrier or enabler of farmers' capacity to adapt to climate change. For the most part, the empirical literature is limited to simple analyses, focusing on either the networks of relationships among rural farmers or on the perspectives of scientists and knowledge producers independently (Munoz-Erickson and Cutts, 2016; Kalafatis et al., 2015; Prell et al., 2009).

These studies, however, lack the much-needed context sensitive systemic description (Lahsen, 2010; Bodin and Crona, 2008; Lahsen and Nobre, 2007), which is needful to design effective knowledge to action systems for farmers' adaptation to climate change. As concurred by Dougill et al.(2016) and Vance-Borland and Holley(2011), the pattern of flow of climate information through organizational networks and the factors that facilitate or impede the flow and use of such information are among areas that need to be studied for a comprehensive understanding of farmers' capacity to adapt to climate change.

This study examines how the organizational collaboration processes around the generation and dissemination of climate risk warning and risk response information acts as either barrier or enabler of information to rural farmers in Ghana. The following research questions were explored:

$R Q 1$. How does the collaboration network either facilitate or hinder climate information flow across scales from national to local?

RQ2. To what extent does the collaboration network promote feedback flow of information from farmers to organizations in the network?

\section{Material and method}

\subsection{Description of the study area and target population}

The study populations are institutions in the climate change and agriculture sectors that are involved in the production and dissemination of information on climate risk warning and risk response strategy in Ghana. In addition, this study interviewed rural farmers in Lawra district, in the Northern region in Ghana. This district was purposefully chosen because of its locations in the semiarid region of Ghana, where rain-fed farming is a major source of livelihood. 
IJCCSM

13,1

22
The Lawra District (Figure 1) is one of the nine districts in Ghana's Upper West Region of north Ghana (Ministry of Food and Agriculture, 2012). The people living in rural areas make up about $88.2 \%$ of the district's population. Livestock keeping and crop farming are the major agricultural livelihood practiced in the district (Ghana Statistical Service, 2013).

\subsection{Survey design and data collection}

Data for the study are triangulated from three data gathering process: review of literatures and grey literatures on agriculture in Ghana, key informant interview (KII) and household questionnaire survey. Organizations that were cited in two or three of the data gathering process were used in defining the key actors in the climate information network in Ghana with respect to farming (Table 1).

The KII questions focused on identifying the organizations' collaborations in the generation and dissemination of climate information, the timescale of climate forecasts that

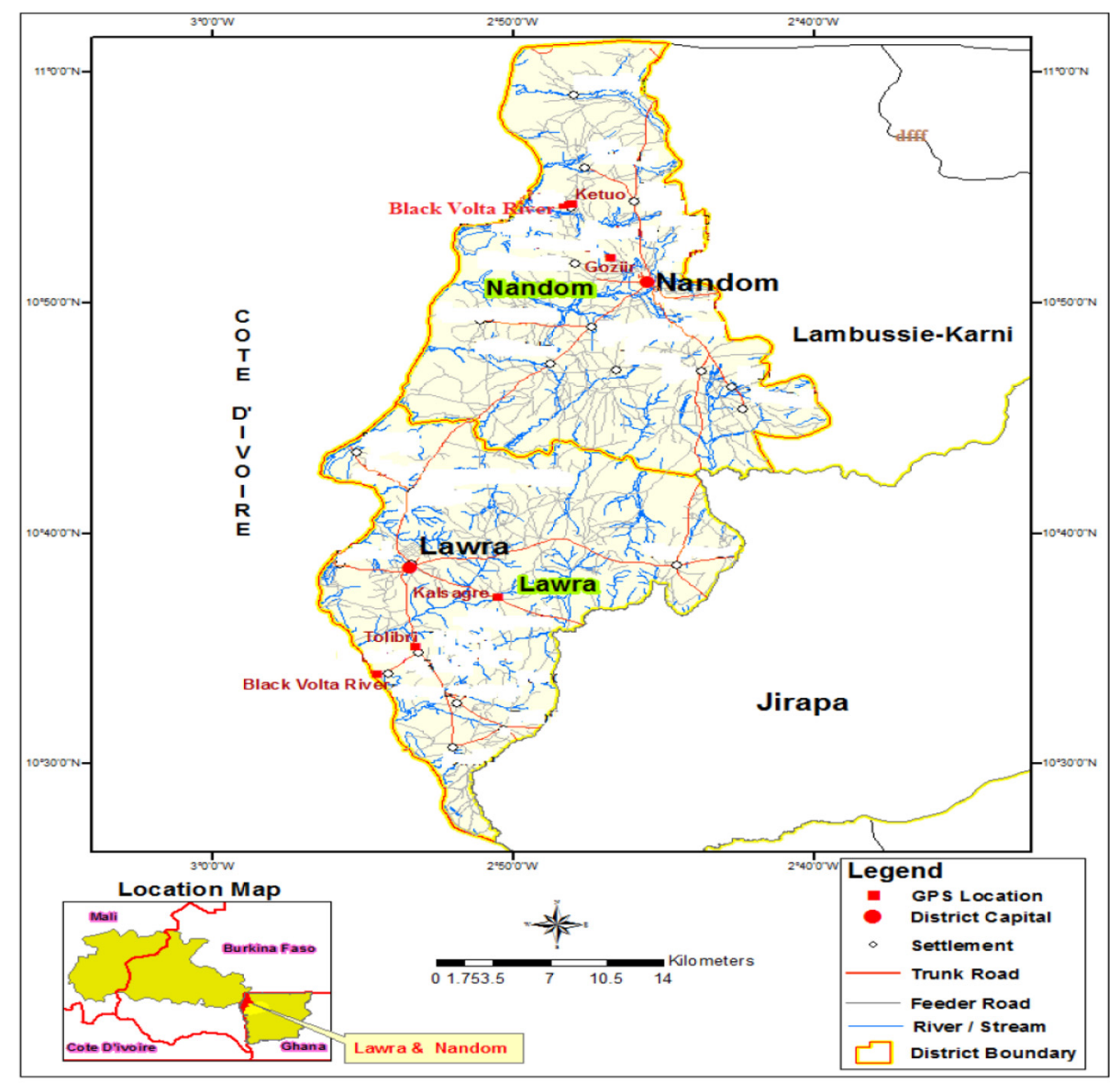

Source: Ghana Statistical Service, GIS
Figure 1. Map of Lawra District 


\begin{tabular}{|c|c|c|c|c|}
\hline No. & Acronym & Type & Name & \multirow{3}{*}{$\begin{array}{l}\text { Climate } \\
\text { information } \\
\text { communication }\end{array}$} \\
\hline 1 & ESOKO Ghana & NGO & ESOKO & \\
\hline 2 & GMET & Government & Ghana Meteorological Agency & \\
\hline 3 & NANDIRDEP & NGO & $\begin{array}{l}\text { Nandon Dunery Rural Integrated } \\
\text { Development Program }\end{array}$ & \multirow{4}{*}{23} \\
\hline 4 & GNFS & Government & Ghana National Fire Service & \\
\hline 5 & EPA & Government & Environmental Protection Agency & \\
\hline 6 & PRUDA & NGO & $\begin{array}{l}\text { Partnership For Rural Development } \\
\text { Action }\end{array}$ & \\
\hline 7 & DPU & Government & Development Planning Unit & \\
\hline 8 & PCCFS & Government & $\begin{array}{l}\text { Platform for Climate Change and Food } \\
\text { Securities }\end{array}$ & \\
\hline 9 & NADMO & Government & $\begin{array}{l}\text { National Disaster Management } \\
\text { Organization }\end{array}$ & \\
\hline 10 & CERSGIS & Research organization & Centre for Remote Sensing and GIS & \\
\hline 11 & OXFAM & International organization & Oxfam & \\
\hline 12 & MOFA & Government & Ministry of Food and Agriculture & \\
\hline 13 & CCAFS & NGO & $\begin{array}{l}\text { Climate Change, Agriculture and Food } \\
\text { Security }\end{array}$ & \\
\hline 14 & CIKOD & NGO & $\begin{array}{l}\text { Center for Indigenous Knowledge and } \\
\text { Organizational Development }\end{array}$ & \\
\hline 15 & RIPS, University of Ghana & Government & Regional Institute for Population Studies & \\
\hline 16 & $\mathrm{DFC}$ & Government & District Forestry Commission & \\
\hline 17 & PICA & Government & $\begin{array}{l}\text { Participatory Integrated Climate Smart } \\
\text { Agriculture }\end{array}$ & \multirow{5}{*}{$\begin{array}{r}\text { Table } 1 . \\
\text { Organizations that } \\
\text { participated in the } \\
\text { KIIs }\end{array}$} \\
\hline \multirow{4}{*}{$\begin{array}{l}18 \\
19 \\
20\end{array}$} & Greener Impact & NGO & Greener Impact Ghana & \\
\hline & SARI & Research organization & Savannah Agricultural Research Institute & \\
\hline & Radio Freed & $\mathrm{CBO}$ & Foundation for Rural Education & \\
\hline & & & Empowerment and Development & \\
\hline
\end{tabular}

the organizations either generates, disseminate or uses in their operations. The KII also included questions on the organization's background and sphere of operation.

The household questionnaire was conducted on the rural farmers to contrast with the results of the KII. Farmers in the rural communities of Baga and Dasuri, both in Lawra District, were interviewed to understand rural farmers' perspective of the relevancy and usability of disseminated climate information. The spatial map of the rural communities was used to stratify each community into five strata based on settlement pattern. From each strata, the researchers randomly sampled four farmers culminating into 20 farmers per community. This represents an average sampling intensity of $6 \%$ per community. Although a minimum of $10 \%$ sampling intensity is recommended for social survey (David, 1987), however, because of the small population and homogeneity among the rural farmers in Ghana, the researchers reckon that $6 \%$ sampling intensity with $5 \%$ error margin is sufficient.

The questionnaire contains questions on the respondents' source of information on climate change and their perception of the relevancy and usability of the information. Respondents were also asked about the nature and scale of information they receive whether weather, climate short term, climate medium term, climate long term and/or decadal.

\subsection{Analysis}

Data from the KII and household survey was analyzed using both quantitative and qualitative techniques. In addition, network analysis was used to analyse data on relation of 
IJCCSM

13,1

24

collaboration between organizations in the generation and dissemination of climate information so as to tease out factor shaping information flow and adoption.

Data on respondents' perceptions about their organization roles in climate information generation and dissemination, influence in the collaboration network, timescale of climate forecasts at organization's disposal and perceived effect of organizations' characteristics as either enabler or barrier of knowledge flow were extracted from household survey and KII and were analyzed using SPSS version 20 (IBM Corp., 2011). Chi-square test was used to analyse the data and a $P$-value of $P<0.05$ represented statistical significance.

The network analysis was aimed at exploring how the structure and cohesion of the collaboration networks acts as either enabler or barrier of information flow. Respondents' responses were coded as either 1 (presence) or 0 (absence) of a collaboration tie in either the generation or dissemination of climate information. Network data were analyzed and visualized using the UCINET 6.0 and NETDRAW 2.0 software (Borgatti et al., 2002). The network structure was analyzed using the clustering coefficient. The network cohesion was analyzed using the density and degree centrality. Degree centrality is useful for identifying organizations influence in the network (Vance-Borland and Holley, 2011).

\section{Results}

\subsection{Relation of collaboration in climate information production}

Generation of relevant risk response is a prerequisite in the adaptation of local farmers to climate change impact. The climate information production network that emerged is composed of 31 organizations (Table 2) that were most frequently mentioned as sources of climate information for rural farmers in Ghana. The international organizations activities are mostly limited to the funding of projects on the generation of information on climate risk and risk response strategy. This is mostly done through the funding of national organizations, e.g. the Ghana Meteorology Agency (GMET), in knowledge generation projects. There are also few instances where international organizations, e.g. the TransAfrican Hydro-Meteorological Observatory (TAHMO), work in partnership with the national organization (GMET) in information generation. However, there are few instances in which international organizations (mostly nongovernmental organizations [NGOs]) are directly involved in information generation activity.

Table 2.

Organizations in the production network according to sphere of operation

\begin{tabular}{lcl}
\hline Sphere of operation/category & Frequency & Members \\
\hline International & 7 & CARE International, Greener Impact, OXFAM, PICA, \\
National & 9 & $\begin{array}{l}\text { TAHMO, UNDP, USAID } \\
\text { EPA, Fish industry, GMET, GNFS, GSD, GSS, GWS, } \\
\text { MOFA, NADMO }\end{array}$ \\
Edistrict & 2 & DFC, DPU \\
Local & 6 & AGRI, CERSGIS, CSIR, RIPS, SARI, School \\
& 7 & CIKOD, Community radio, ESOKO, NANDRIDEP, NGO, \\
& & PCCFS, PRUDA
\end{tabular}

Notes: PICA - Participatory Integrated Climate Smart Agriculture; TAHMO - Trans-African Hydro Meteorological Observatory; UNDP - United Nations Development Program; GSD - Geological Service Department; GSS - Ghana Statistical Service; GWS - Ghana Wildlife Society; NADMO - National Disaster Management Organization; DPU - Development Planning Unit; AGRI - Agriculture Research Institute; CERSGIS - Centre for Remote Sensing and GIS; CSIR - Council for Scientific and Industrial Research; and RIPS - Regional Institute for Population Studies 
The organizations operating at the national level are mostly government ministries, agencies and departments. Their activities are mostly focused on the generation of information on a national scale on climate risk and risk response strategy. The scale of information being generated at this level includes weather, seasonal, multi-year (1-5 years) intra-decadal (5-10 years) and decadal information. The government ministries particularly the Ministry of Food and Agriculture (MOFA) acts as boundary organizations in the network focusing on translation of climate data into information on climate risk warning and risk response relevant for the agriculture sector. At the local level, NGOs and community-based organizations are the most involved in the collation and dissemination of local-scale information on climate risk warning and risk response strategy.

The analysis of organizational collaborations in the climate information production network (Figure 2) reveals a complex interaction that shapes information flow and adoption by local farmers. The information production network has an overall density of 0.425 , i.e. $43 \%$. This indicates a moderate link (connection or relations) among the organizations that make up the network.

The core periphery analysis indicated that the network has a fit correlation of 005178. Also the following actors: District Development Planning Unit (DPU), Community Radio, MOFA, Centre for Indigenous Knowledge and Organizational Development (CIKOD), OXFAM, NGOs, District Forestry Commission (DFC), Nandon Dunery Rural Integrated Development Program (NANDRIDEP), GMET and ESOKO were identified as the core actors of the network. Furthermore, the researchers calculated the clustering coefficient of the network to understand how quickly knowledge can flow through the network. The overall clustering coefficient of the

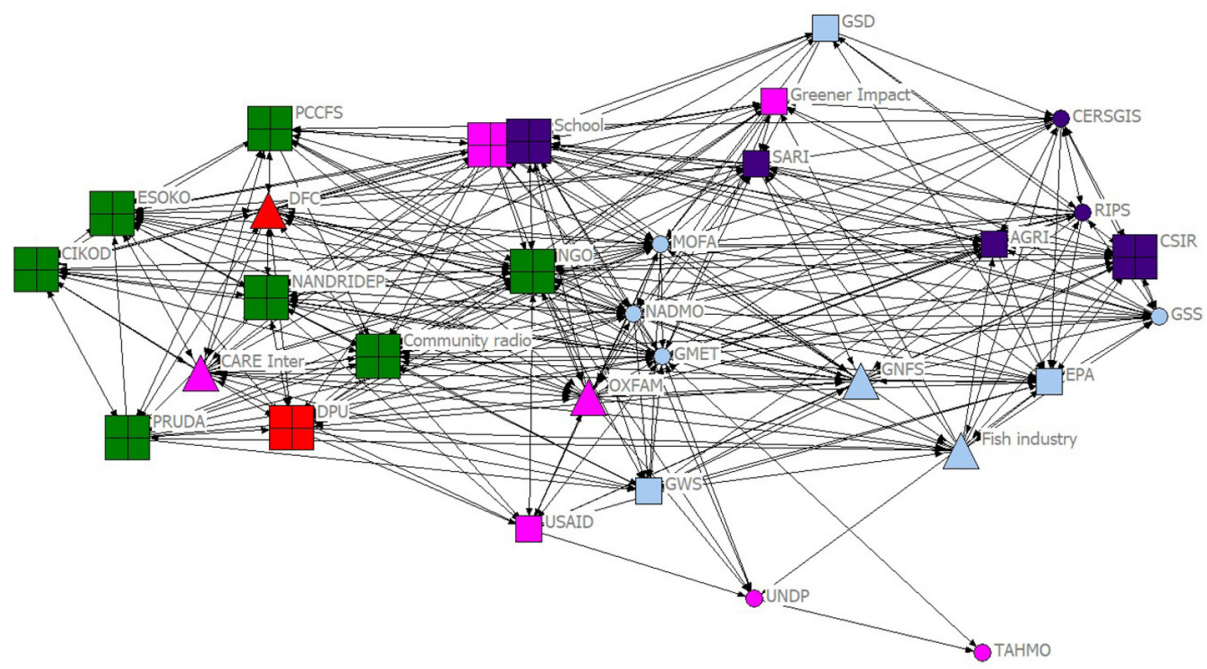

Notes: Nodes were colored based on the administrative operation level of each stakeholder (pink: international, light blue: national, red: district, navy blue: educational and research organization, green: local NGOs/CBOs. Node shapes were based on scale of climate knowledge being produced (weather, seasonal, multi-year 1-5 years, intra-decadal (5-10 years) and decadal 10years+; circle: organizations producing all five categories, square: organizations producing any four of the categories, up triangle: organization producing any three of the categories, box: organizations producing weather and seasonal categories)

\section{Climate information communication}

Figure 2. Climate information production network representing collaboration relations among stakeholders with respect to local level farming in Ghana 
IJCCSM

13,1

26

network was observed to be 0.560 . The individual clustering coefficient of the core actors in the network along with their reciprocity is presented in Table 3.

Apart from CIKOD and ESOKO, all organizations in the production network have moderate to low clustering coefficient and moderate reciprocity. This indicates poor collaborations and flow of information in the production network. Finally, degree centrality measure of network cohesion was calculated to determine the organizations influence on information flow in the network. The network was observed to have an overall $0.4195^{\circ}$ centralization. Based on degree centralization, GMET (29), MOFA (28) and NGOs (26) were identified as the top three central actors. The central actors contain a mix of governmental and civic organizations, which is an indication of the increasingly important role that civic organizations are playing in climate information generation in Ghana.

\subsection{Relation of collaboration in climate information dissemination}

The information dissemination network that emerged is composed of 32 organizations (Table 4) that were most frequently mentioned as sources of adaptation knowledge for rural farmers in Ghana. The international organizations activities are mostly based on funding of learning by doing activities. This is often done directly or indirectly through the funding of

\begin{tabular}{llccc}
\cline { 2 - 4 } & Organizations & $\begin{array}{c}\text { Clustering } \\
\text { coefficient (\%) }\end{array}$ & $\begin{array}{c}\text { Total number } \\
\text { of possible } \\
\text { ties }\end{array}$ & $\begin{array}{c}\text { Reciprocity in } \\
\text { percentage } \\
\text { (symmetric) }\end{array}$ \\
\cline { 2 - 5 } & CIKOD & 74 & 91 & 1 \\
& Community radio & 54 & 210 & 0.476 \\
& DFC & 62 & 171 & 0.737 \\
& DPU & 56 & 136 & 0.588 \\
Table 3. & GMET & 72 & 120 & 0.750 \\
Clustering coefficient & NOFA & 41 & 406 & 0.552 \\
and reciprocity of & NANDRIDEP & 45 & 378 & 0.679 \\
core actors in the & OXFAM & 48 & 276 & 0.333 \\
production network & School & 58 & 190 & 0.700 \\
& & 44 & 325 & 0.654 \\
\hline
\end{tabular}

Sphere of operation/

category Frequency Members

International 6 Abibimman Foundation, AYICC, CARE International, CSAYN,

National

Greener Impact, OXFAM

Policymakers, VRA

Table 4.

Organizations in the dissemination

District

3

Education and

network according to

$\begin{array}{ll}\text { Local } & 7\end{array}$

5 AGRI, RIPS, SARI,

the sphere of

operation

Note: AYICC - The African Youth Initiative on Climate Change 
locally based NGOs to carry out field demonstration activities at the rural communities to teach the farmers various types of climate-smart farming activities. Some of the activities that have been carried out in this regard include training on ridge farming, training on the choice of varieties of crops for the next two to three planting seasons based on seasonal climate forecast, training on compost making, training on dry season vegetable farming and provisioning of information on information on when to plant in case of either early or delay onset of rain. The aim is to ensure that planted crops get sufficient rain for maturity before the rain stops.

The organizations operating at national to district level in climate information dissemination are mostly made up of governmental organizations. Their activities in information dissemination are mostly done through existing governmental structure, whereby information generated by the national office is disseminated through the district offices operating at the community level. In most cases, the district offices operate in partnership with local NGOs for downscaling and generation of the local relevant climate information for the farmers. The scale and nature of information disseminated through the network is mostly weather and seasonal information. Educational and research organization are sparingly engaged directly in information dissemination to farmers.

The structure and cohesion of the information dissemination network (Figure 3) have a significant influence on information flow. The dissemination network has an overall network density of 0.465 . This indicates a moderate link (connection or relations) among the

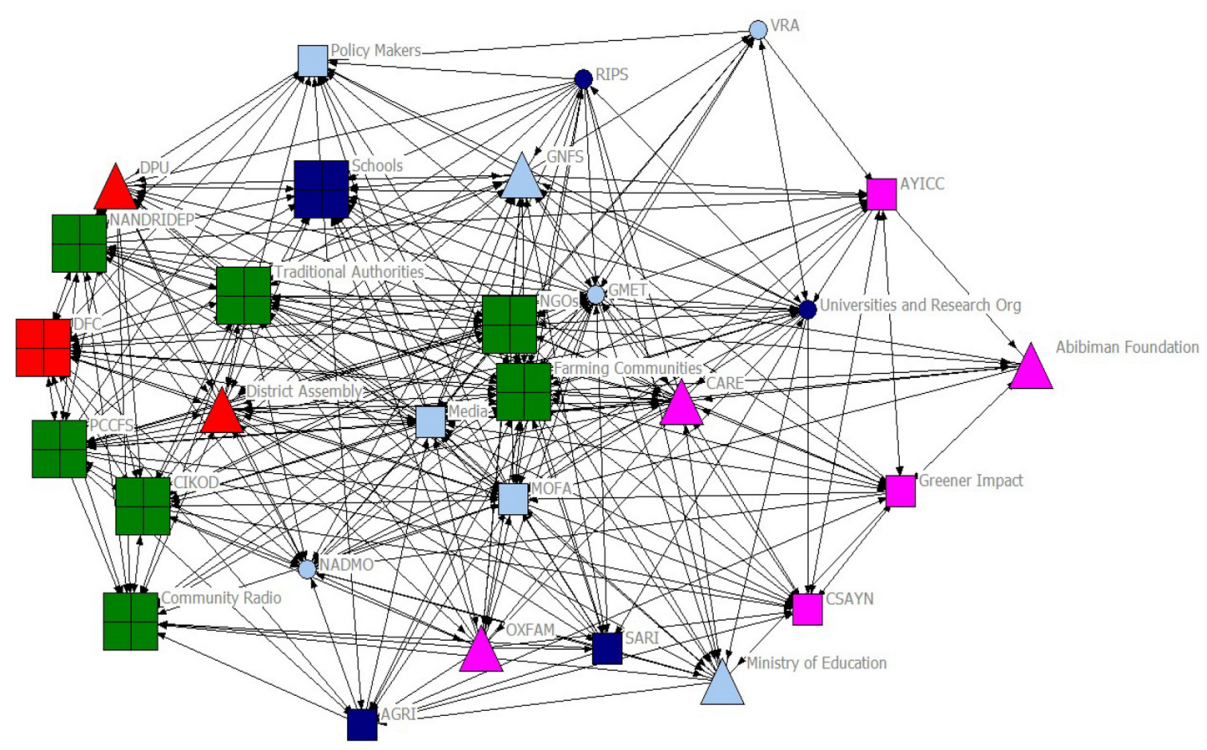

Notes: Nodes were colored based on the administrative operation level of each stakeholder (pink: international, light blue: national, red: district, navy blue: educational and research organization, green: local NGOs/CBOs. Node shapes were based on scale of climate knowledge being produced (weather, seasonal, multi-year $1-5$ years, intra-decadal (5-10 years), and decadal; circle: organizations disseminating all five categories, square: organizations disseminating any four of the categories, up triangle: organization disseminating any three of the categories, box: organizations disseminating weather and seasonal categories)

Figure 3. Climate information dissemination network representing collaboration relations among stakeholders with respect to local level farming in Ghana 
IJCCSM

13,1

28

organizations that make up the network. The degree centrality measure indicated that farming communities (28), GMET (27), media (27), NGOs (26) and MOFA (25) are the top central actors that serve as central sources of information for the rest of the organizations in the network.

Based on core/periphery analysis, the following actors CARE International, CIKOD, DFC, District Assembly, DPU, Farming Communities, GMET, Ghana National Fire Service (GNFS), Media, MOFA, NADMO, NGOs, Platform for Climate Change and Food Securities (PCCFS) and Traditional Authorities were identified as the network core actors. The dissemination network was observed to have an overall clustering coefficient of 0.5886 . The individual clustering coefficient of the core organizations in the network is presented in Table 5 along with the actor's reciprocity.

Most of the core actors in the dissemination network have a moderate to high clustering coefficient. However, their reciprocity is slightly low. This indicates that many of the collaboration in the network are not reciprocated.

\subsection{Organizational network connectedness to rural farmers}

Farmers' level of contact with organizations in the climate change and farming sector is intrinsic to their access to climate information. This study surveyed rural farmers in the Bagri and Dasuri communities of Lawra District, Ghana, so as to gain practical knowledge of their level of connection with the organizations operating in the climate change and agriculture sector. The average years of experience of the interviewed farmers were 22 years.

3.3.1 Frequently consulted organizations. Farmers were asked to list the top five organizations they most frequently consult for information on climate risk and risk response strategy. All interviewed farmers mentioned three organizations they each consult (Table 6).

There are few organizations that are occasionally consulted by the local farmers when sourcing climate information. These organizations include NANDRIDEP, Traditional authority and members of the district assembly. Farmers generally turn to these

\begin{tabular}{lccc}
\hline Organizations & $\begin{array}{c}\text { Clustering } \\
\text { coefficient }(\%)\end{array}$ & $\begin{array}{c}\text { Total number } \\
\text { of possible } \\
\text { ties }\end{array}$ & $\begin{array}{c}\text { Reciprocity in } \\
\text { percentage } \\
\text { (symmetric) }\end{array}$ \\
\hline CARE & & & \\
International & 54 & 210 & 0.429 \\
CIKOD & 66 & 153 & 0.722 \\
DFC & 64 & 153 & 0.722 \\
District & & & 0.857 \\
Assembly & 56 & 136 & 0.588 \\
DPU & 67 & 378 & 0.893 \\
Farming & & 351 & 0.481 \\
Communities & 43 & 190 & 0.400 \\
GMET & 45 & 351 & 0.519 \\
GNFS & 52 & 300 & 0.320 \\
Media & 45 & 190 & 0.450 \\
MOFA & 47 & 325 & 0.538 \\
NADMO & 59 & 171 & 0.474 \\
NGO & 47 & & 0.474 \\
PCCFS & 60 & 171 & \\
Traditional & & & \\
Authorities & 64 & &
\end{tabular}

Table 5.

Clustering coefficient and reciprocity of core actors in the dissemination network 
organizations because, first, the organizations come to the villages to instruct the farmers, which makes them very accessible; Second, the organizations provide services and facilities to the farmers at no cost, which makes their activities attractive and affordable to the farmers.

\section{Discussion}

4.1 Collaborations in climate information generation and dissemination

Projects on climate information generation and dissemination are mostly funded by international organizations, followed by national agencies and local NGOs. Project funding by external donors is a common occurrence in many developing countries, where governmental organizations are playing very limited role in the funding of projects on climate knowledge generation and dissemination (Ofoegbu et al., 2018). The insufficient engagement of national organizations in the funding of projects on climate information generation and dissemination is an issue of concern. This is because it sometimes leads to a situation where funded projects do not align with country's developmental priority in terms of climate risk management (African Development Bank, 2011). To manage this challenge, improved collaboration between donor organization and core organizations in the network is essential.

The translation forecasts into climate risk warning and agro-advisory services are mostly done at national level. Only a few NGOs were observed to be working collaboratively with governmental organizations at the local level in the generation and communication of local scale climate information to rural farmers. The implication is the increasing reliance on NGOs by local farmers for accessing climate information. The challenge with this model is the uncertainty surrounding the sustained functioning of these local NGOs. Most of the local NGOs' existence and functioning is dependent on the availability of funding that is often not guaranteed for a long term. Climate information production activity is therefore plagued with the problem of sustainability. This type of challenge has been reported in many African countries (Ofoegbu et al., 2018; Never, 2012).

Generally, governmental organizations have the capacity and reach to facilitate smooth information flow across scale from national to a local level using their internal structures. In this regard, bureaucracy was identified as an enabler of knowledge flow among governmental organizations, whereas the same bureaucracy was cited as a barrier to knowledge flow from governmental organizations to either $\mathrm{CBO} / \mathrm{NGO}$ or research organizations. Similarly, some NGOs, mostly international, expressed the challenge of false expectation in their collaboration work with governmental organizations. There are also some challenges associated with collaborations among civic organizations. The challenge of trust (mistrust of partner snatching funding relationship with funding partners), poor funding and insufficient capacity (in terms of staff number and quality) is a common challenge to knowledge flow in collaborations among civic organizations. In the same vein,

\begin{tabular}{lccccccrr}
\hline & \multicolumn{7}{c}{ Mentioned collaborating organization } & \\
Knowledge classification & MOFA & ACDEP & NGO & ESOKO & CCAFS & CARE & CIKOD & Organization \\
\hline Weather & 11 & 6 & 3 & 5 & 2 & 1 & 2 & consulted for \\
Seasonal & 11 & 6 & 3 & 5 & 2 & 1 & 2 & information on \\
Multi-years (1-5 years) & 2 & 1 & 1 & 0 & 0 & 1 & 0 & climate risk and risk \\
Intra-decadal (5-10 years) & 2 & 1 & 0 & 0 & 0 & 0 & 0 & response strategy \\
Decadal (10 years and above) & 1 & 0 & 0 & 0 & 0 & 0 & 0 \\
\hline
\end{tabular}


IJCCSM

13,1

collaboration between private organizations and civic organizations sometimes experience conflicts because of differences in organizational goals. Private organizations are profitoriented in project execution, whereas NGOs are not; this often leads to conflict in their collaborations on climate information generation and dissemination. Collaborations among governmental organizations are challenged with issues such as lack of interest, and lack of political will. Also, traditional authorities and local organizations often expressed the challenge of interference from powers (politician and influential people) as a hindrance to the implementation of climate adaptation-related by-laws in their community. There is, therefore, the need for exploration of modalities to facilitate and improve collaborations across organizations types, given the fact that the central actors in the network are composed of governmental, NGOs and private organization. Improving collaboration across organizational types is therefore essential.

\subsection{Farmers perception of information relevance and usability}

Both the KII and questionnaire survey process revealed that the climate information communicated to rural farmers is mostly derived from weather and seasonal forecasts. The lack of use of longer term forecasts in the generation of climate information communicated to rural farmers could be because:

- Most of the farmers are poor and lack resources to pursue long-term adaptation action. Hence they tend to focus mostly on solving their socioeconomic challenges on day-to-day basis. This notion is supported by quote from some of the interviewed farmers, "I prefer the weather information because it's more suitable to our daily farming operations especially during the planting seasons - Dasuri farmer."

- Another attributable reason for lack of use of long-term forecasts in climate information generation is the supply and demand factor.

Given the socioeconomic limitation of the farmers to pursue long term-adaptation plan, the organizations operating in the farmers' communities are compelled to focus on supplying or satisfying farmers' climate information need. Most rural farmers have adopted highly flexible livelihood strategy and, consequently, have less need for long-term information. Such farmers usually adopt migration and off-farm livelihood practices in response to temporal climate change impacts (Ofoegbu and New, 2020).

The location of rural farmers in the core of the climate information dissemination network suggests that farmers are at the least in the center of all actions. There is a consistency in the farmers' preferred information scale and scale of information generated and disseminated by organizations in the farmers' adaptation network. The centralization of NGOs in both the information production and dissemination networks has greatly increased the generation and dissemination of locally relevant information to the rural farmers. The NGOs disseminate information through the process of learning by doing. Using this approach, NGOs use field demonstration to teach the farmers how to adopt new climatesmart practices. This approach facilitates the dissemination of contextual information and also enhances the farmers' capacity to adopt the information (Kruk et al., 2017).

Furthermore, the poor reciprocity and density of the information dissemination network suggests that poor feedback relation and collaboration among the organization in the network is hindering effectiveness of climate information communication to rural farmers. Though information dissemination to rural farmers seems to cover all identified climate-related challenges in the communities, the poor feedback is reflected in the failure to capture other social and farming challenges impacting farming sustainability in the community (Ouedraogo et al., 2018). The challenges of weed management, livestock conflict etc., are some of the issues 
hampering farming practices in the local communities that are not yet being addressed by relevant organizations (MOFA and others) in the farmers' adaptation network.

\section{Climate information communication}

\section{Conclusion}

The translation of climate forecasts to tailored climate risk warning and risk response advisory service that is usable in the agriculture sector and relevant to the specific contexts of rural farmers in the different region of a country is a resource-intensive process that can be tainted by the relatively small number of transdisciplinary scientists available and the highly diverse context of the users. This study makes several important contributions to both the science and practice of weather and climate forecasts translation into adaptation action with respect to rural farmers' adaptation to climate change. The collaborations among the institutions in the climate change and agriculture sectors can operate as vehicles for enhancing the usefulness of climate information to local farmers' adaptation practices.

This study has made important contributions on the structure and properties of the climate information production and dissemination network in Ghana and the influence of the network structure and cohesion on information flow. Both the information production and dissemination networks displayed moderately high density and cohesion. Both networks indicate the existence of a smooth flow of collaborative and exchange relations among the different organizations that make up the networks. Nevertheless, maintaining iteration and feedbacks loop in the collaborations that exist among organizations operating in the climate information network is key to enhancing the usefulness of climate information.

In terms of the connectedness of organizational networks to rural farmers, this study revealed a facilitated top-down collaboration among governmental organizations and a challenged feedback (bottom-up) collaboration. Hence, this study calls for a more robust approach to enhance reciprocity in collaborations in both networks as a means of sustaining the production, dissemination and tailoring of climate information to the context of rural farmers.

\section{References}

Abrahamson, E. and Rosenkopf, L. (1997), "Social network effects on the extent of innovation diffusion: a computer simulation”, Organization Science, Vol. 8 No. 3, pp. 1-21.

Adger, N., Benjaminsen, T., Brown, K. and Svarstad, H. (2001), "Advancing a political ecology of global environmental discourses", Development and Change, Vol. 32 No. 4, pp. 681-715.

African Development Bank (2011), "The cost of adaptation to climate change in Africa", available at: www.afdb.org/fileadmin/uploads/afdb/Documents/Project-and-Operations/Cost\%20of\%20Adaptation \%20in\%20Africa.pdf (accessed 25 August 2018).

Bodin, O. and Crona, B.I. (2008), "Management of natural resources at the community level: exploring the role of social capital and leadership in a", World Development, Vol. 36 No. 12, pp. 2763-2779.

Bodin, O. and Crona, B.I. (2009), "The role of social networks in natural resource governance: what relational patterns make a difference?", Global Environmental Change, Vol. 19 No. 3, pp. 366-374.

Borgatti, S.P., Everett, M.G. and Freeman, L.C. (2002), Ucinet for Windows: Software for Social Network Analysis, Harvard Analytic Technologies, Harvard, MA.

Cadger, K., Quaicoo, A.K., Dawoe, E. and Isaac, M.E. (2016), "Development interventions and agriculture adaptation: a social network analysis of farmer knowledge transfer in Ghana", Agriculture, Vol. 6 No. 3, pp. 1-14. 
IJCCSM 13,1

Cárcamo, P.F., Garay-Flühmann, R. and Gaymer, C.F. (2014), "Collaboration and knowledge networks in coastal resources management: how critical stakeholders interact for multiple-use marine protected area implementation", Ocean and Coastal Management, Vol. 91, pp. 5-16.

Cash, D.W. and Moser, S.C. (2000), "Linking global and local scales: designing dynamic assessment and management processes", Global Environmental Change, Vol. 10 No. 2, pp. 109-120.

Cooper, P.J.M., Dimes, J., Rao, K.P.C., Shapiro, B., Shiferaw, B. and Twomlow, S. (2008), “Coping better with current climatic variability in the rain-fed farming systems of Sub-Saharan Africa: an essential first step in adapting to future climate change?", Agriculture, Ecosystems and Environment, Vol. 126 Nos 1/2, pp. 24-35.

Cornell, S., Berkhout, F., Tuinstra, W., Tabara, J.D., Jager, J., Chabay, I., de Wit, B., Langlais, R., Mills, D., Moll, P., Otto, I.M., Petersen, A., Pohl, C. and van Kerkhoff, L. (2013), "Opening up knowledge systems for better responses to global environmental change", Environmental Science and Policy, Vol. 28, pp. 60-70.

Coulibaly, Y.J., G., Kundhlande, N., Tall, A., Kaur, H. and Hansen, J. (2015), "What climate services do farmers and pastoralists need in Tanzania? Baseline study for the GFCS adaptation program in Africa”, CCAFS Working Paper no. 110, CGIAR Research Program on Climate Change, Agriculture and Food Security (CCAFS), Copenhagen, Denmark, available at: https:/ccafs.cgiar. org/publications/what-climate-services-do-farmers-and-pastoralists-need-tanzania\#.X3mYk2gzZaQ (accessed 1 June 2018).

Cramer, L. (2017), "Evaluation of climate services interventions in the GFCS adaptation programme for Africa. Part II: beneficiary assessment", available at: https://research.reading.ac.uk/picsa/wpcontent/uploads/sites/76/2019/02/Final-report_1-Nov-2017-min.pdf (accessed 15 February 2018).

David, A.K. (1987), Statistics for the Social and Behavioral Sciences, Little, Brown, Boston.

Dayamba, D.S., Ky-Dembele, C., Bayala, J., Dorward, P., Clarkson, G., Sanogo, D., Mamadou, L.D., Traoré, I., Diakité, A., Nenkam, A., Binam, J.N., Ouedraogo, M. and Zougmore, R. (2018), "Assessment of the use of participatory integrated climate services for agriculture (PICSA) approach by farmers to manage climate risk in Mali and Senegal", Climate Services, pp. 1-9, doi: 10.1016/j.cliser.2018.07.003.

De Pinto, A., Demirag, U., Haruna, A., Koo, J. and Asamoah, M. (2012), “Climate change, agriculture, and foodcrop production in Ghana”, International Food Policy Research Institute Policy Note \#3, 1-6, available at: https://media.africaportal.org/documents/gssppn3.pdf (accessed 20 January 2018).

Dougill, A.J., Whitfield, S., Stringer, L.C., Vincent, K., Wood, B.T., Chinseu, E.L., Steward, P. and Mkwambisi, D.D. (2016), "Mainstreaming conservation agriculture in Malawi: knowledge gaps and institutional barriers", Journal of Environmental Management, Vol. 195 No. Part 1, pp. 1-10.

Fosu-Mensah, B.Y., Vlek, P.L.G. and MacCarthy, D.S. (2012), "Farmers' perception and adaptation to climate change: a case study of Sekyedumase district in Ghana", Environment, Development and Sustainability, Vol. 14 No. 4, pp. 495-505.

Ghana Statistical Service (2013), “2010 Population and Housing Census: Upper West Regional Analytical Report Accra”, Ghana Statistical Service.

Holler, J. (2014), "Adaptation policy and adaptation realities: local social organization and crossscale networks for climate adaptation on mount Kilimanjaro”, GeoJournal, Vol. 79 No. 6, pp. 737-753.

IBM Corp (2011), IBM SPSS Statistics for Windows, Version 20.0, IBM Corp, Armonk, New York, NY.

Kadushin, C. (2012), Understanding Social Networks: Theories, Concepts, and Findings, Oxford University Press.

Kalafatis, S.E., Lemos, M.C., Yun-Jia, L. and Frank, K.A. (2015), "Increasing information usability for climate adaptation: the role of knowledge networks and communities of practice", Global Environmental Change, Vol. 32, pp. 30-39. 
Kemausuor, F., Dwamena, E., Bart-Plange, A. and Kyei-Baffour, N. (2011), "Farmers' perception of climate change in the Ejura-Sekyedumase district of Ghana", ARPNJournal of Agricultural and Biological Science, Vol. 6 No. 10, pp. 1-12.

Kruk, M.C., Parker, B., Marra, J.J., Werner, K. and Heim, R. (2017), "Engaging with users of climate information and the coproduction of knowledge", Weather, Climate, and Society, Vol. 9 No. 4, pp. 839-849.

Lahsen, M. (2010), "The social status of climate change knowledge: an editorial essay", Wiley Interdisciplinary Reviews: Climate Change, Vol. 1 No. 2, pp. 162-171.

Lahsen, M. and Nobre, C.A. (2007), "The challenge of connecting international science and local level sustainability: the case of the LBA", Environmental Science and Policy, Vol. 10 No. 1, pp. 62-74.

Machingura, F., Nyamwanza, A., Hulme, D. and Stuar, E. (2018), "Climate information services, integrated knowledge systems and the 2030 agenda for sustainable development”, Sustainable Earth, doi: 10.1186/s42055-018-0003-4.

Marm, A. and Berkes, F. (2010), "Network approach for understanding small-scale fisheries governance: the case of the Chilean coastal co-management system", Marine Policy, Vol. 34 No. 5 , pp. 851-858.

Ministry of Food and Agriculture (2012), "Lawra”, MOFA, available at: http://mofa.gov.gh/site/? page_id=1673 [June 6, 2018]

Munoz-Erickson, T.A. and Cutts, B.B. (2016), "Structural dimensions of knowledge-action networks for sustainability", Current Opinion in Environmental Sustainability, Vol. 18, pp. 56-64.

Ndamani, F. and Watanabe, T. (2015), "Farmers' perceptions about adaptation practices to climate change and barriers to adaptation: a micro-Level study in Ghana”, Water, Vol. 7 No. 12, pp. 4593-4604.

Never, B. (2012), Knowledge Systems and Change in Climate Governance: Comparing India and South Africa, Routledge, London, 10.4324/9781315796550. (accessed 25 September 2018).

Ofoegbu, C. and New, M. (2020), "Collaboration relations in climate information production and dissemination to subsistence farmers in Namibia", Environmental Management, doi: 10.1007/ s00267-020-01383-5.

Ofoegbu, C., New, M.G. and Staline, K. (2018), "The effect of inter-organisational collaboration networks on climate knowledge flows and communication to pastoralists in Kenya", Sustainability, Vol. 10 No. 11, pp. 1-23.

Oreszczyn, S., Lane, A. and Carr, S. (2010), "The role of networks of practice and webs of influencers on farmers' engagement with and learning about agricultural innovations", Journal of Rural Studies, Vol. 26 No. 4, pp. 404-417.

Ouedraogo, I., Diouf, N.S., Ouédraogo, M., Ndiaye, O. and Zougmoré, R.B. (2018), "Closing the gap between climate information producers and users: assessment of needs and uptake in Senegal”, Climate, Vol. 6 No. 1, pp. 131-116.

Prell, C., Hubacek, K. and Reed, M. (2009), "Stakeholder analysis and social network analysis in natural resource management", Society and Natural Resources, Vol. 22 No. 6, pp. 501-518.

Stott, C. and Huq, S. (2014), "Knowledge flows in climate change adaptation: exploring friction between scales", Climate and Development, Vol. 6 No. 4, pp. 382-387.

Tall, A., Coulibaly, J.Y. and Diop, M. (2018), "Do climate services make a difference? A review of evaluation methodologies and practices to assess the value of climate information services for farmers: implications for Africa”, Climate Services, Vol. 11, pp. 1-12.

Vance-Borland, K. and Holley, J. (2011), "Conservation stakeholder network mapping, analysis, and weaving”, Conservation Letters, Vol. 4 No. 4, pp. 278-288.

World Bank (2013), "Turn down the heat: climate extremes, regional impacts, and the case for resilience", A report for the World Bank by the Potsdam Institute for Climate Impact Research 
IJCCSM

13,1

34

and Climate Analytics", Washington, DC: World Bank. License: Creative Commons Attribution Non Commercial - No Derivatives3.0 Unported license (CC BYNC-ND 3.0), www.worldbank.org/ en/topic/climatechange/publication/turn-down-the-heat-climate-extremes-regional-impacts-resilience_ [January_20,_2019]

Wossen, T., Berger, T., Swamikannu, N. and Ramilan, T. (2014), "Climate variability, consumption risk and poverty in semi-arid Northern Ghana: adaptation options for poor farm households", Environmental Development, Vol. 12, pp. 2-15.

\section{Further reading}

Brooks, S. and Loevinsohn, M. (2011), "Shaping agricultural innovation systems responsive to food insecurity and climate change", Natural Resources Forum, Vol. 35 No. 3, pp. 185-200.

Clewer, A.G. and Scarisbrick, D.H. (2001), Practical Statistics and Experimental Design for Plant and Crop Science, John Wiley and Sons, Ltd., West Sussex England, pp. 1-22.

Conley, T. and Udry, C. (2001), "Social learning through networks: the adoption of new agricultural technologies in Ghana", American Journal of Agricultural Economics, Vol. 83 No. 3, pp. 668-673.

Ghana Statistical Service (2012), "2010 Population and Housing Census: Summary Report of Final Results Accra", Ghana Statistical Service.

Hanneman, R. and Riddle, M. (2005), "Introduction to social network methods", Chapter 10: centrality and power, available at: www.faculty.ucr.edu/ hanneman/nettext/C10_Centrality.html (accessed 4 October 2020).

Isaac, M.E., Erickson, B.H., Quashie-Sam, S. and Timmer, V.R. (2007), "Transfer of knowledge on agroforestry management practices: the structure of farmer advice networks", Ecology and Society, Vol. 12 No. 2, pp. 1-13.

Janssen, M.A., Bodin, Ö., Anderies, J.M., Elmqvist, T., Ernstson, H., McAllister, R.R.J., Olsson, P. and Ryan, P. (2006), "Toward a network perspective on the resilience of social-ecological systems", Ecology and Society, Vol. 11 No. 1, pp. 1-20.

Keller, G. and Warrack, B. (2003), Statistics for Management and Economics, 6th ed., Curt Hinrichs publisher, Pacific Grove, CA, p. 350.

Rombach, M.P., Porter, M.A., Fowler, J.H. and Mucha, P.J. (2014), "Core-periphery structure in networks", Siam Journal on Applied Mathematics, Vol. 74 No. 1, pp. 167-190.

Tall, A., Jay, A. and Hansen, J. (2013), "Scaling up climate services for farmers in Africa and South Asia workshop report”, CCAFS Working Paper no. 40. CGIAR Research Program on Climate Change, Agriculture and Food Security (CCAFS), Copenhagen, Denmark, avilable at: https://cgspace. cgiar.org/bitstream/handle/10568/27833/http:/WP40.pdf (accessed 12 July 2018).

Ville, A.S.S., Hickey, G.M., Locher, U. and Phillip, L.E. (2016), "Exploring the role of social capital in influencing knowledge flows and innovation in rural farming communities in the Caribbean", Food Security, Vol. 8 No. 3, pp. 535-549.

\section{Corresponding author}

Chidiebere Ofoegbu can be contacted at: ofoegbu.c@gmail.com

For instructions on how to order reprints of this article, please visit our website:

www.emeraldgrouppublishing.com/licensing/reprints.htm

Or contact us for further details: permissions@emeraldinsight.com 